\title{
BRIEF ANALYSIS ON THE IMPACT OF COVID-19 ON THE EUROPEAN ECONOMY
}

\author{
Costel Ceocea \\ "Vasile Alecsandri" University of Bacau, \\ cceocea@sifm.ro, \\ Bogdan Vasile Nichifor \\ "Vasile Alecsandri" University of Bacau, \\ bogdan.nichifor@ub.ro, \\ Laura Cătălina Ţimiraş \\ "Vasile Alecsandri” University of Bacau, \\ timiras.laura@ub.ro
}

\begin{abstract}
In the context in which globalization generates chain reactions, the economic disturbances generated by the Covid-19 crisis are encountered at the global, European and of course regional level and, due to the novelty of the manifestation of the crisis, the capacity of known economic models to provide quick solutions in this context has proved to be limited. Most of the economic imbalances that have occurred are not due to the epidemic itself, but to the measures taken to prevent the spread of this virus. Attempts are being made globally to identify exit scenarios from the crisis. Such scenarios are the result of individual and collective action by states affected by the pandemic. Obviously, the results are different depending on the characteristics, potential, commitment of each of the states / areas affected by the economic crisis and can be evaluated in term of efficiency only after the trigger factor will cease to exist.
\end{abstract}

\section{Keywords}

Covid-19, crisis, economic growth, European Union, recovery solutions

\section{JEL Classification}

F01; G01

\section{Introduction}

The current "Covid-19" crisis has induced unprecedented imbalances in the flow of channels through which the correlation between supply and demand is made, in those specific to the financial-banking and capital market, so that estimates of the global economic evolution of before the onset of the crisis were completely overthrown. Most of the economic imbalances that have occurred are not due to the epidemic itself, but to the measures taken to prevent the spread of this virus. For example, most countries have opted to block activities or self-quarantine as a precautionary measure, encouraging people to stay away from each other, thus closing schools, universities and other public institutions, and placing strict restrictions on both international travel, as well as in internal affairs, also restricting the movement of labor, goods and consumers. Due to the pandemic, most countries have closed their restaurants, cinemas, transportation services, hotels, shops and other businesses that required direct contact with the customer. In the context in which almost 100 countries have closed their national borders since March, the movement of people and tourist flows have stopped (Mishra, 2020).

In a document published in January 2020, the United Nations estimated an increase in world gross product of $2.5 \%$ by 2020. Subsequently, in May 2020, the same organization estimated a decrease of the world economy by $3.2 \%$, and the expected 
production (output) decreases for the period 2020 - 2021 canceling the output gains of the last four years. The decrease of the world economy by $3 \%$ is also estimated by the International Monetary Fund (MFI, 2020), which also estimates that the US economy will contract by $5.9 \%$ this year, the Eurozone by $7.5 \%$, and that of developing economies from Europe with 5.2\% (Naharand and Farhand, 2020). The World Bank, in a darker scenario, estimates a decline in the world economy by $5.2 \%$ in 2020 , appreciating the current crisis that we are going through as the worst in the last 150 years (see table no. 1)

Table 1. Growth of GDP in global recessions

\begin{tabular}{|l|l|l|l|l|l|}
\hline \multirow{2}{*}{ World } & 1975 & 1982 & 1991 & 2009 & 2020 \\
\cline { 2 - 6 } & 1,1 & 0,4 & 1,3 & $-1,8$ & $-5,2$ \\
\hline
\end{tabular}

Source: World Bank Group, Global Economic Prospects, June 2020, pp.17.

In the context in which globalization generates chain reactions, the economic disturbances generated by the Covid-19 crisis, which have not been known before, are encountered globally, and implicitly at European and of course regional level and, due to the novelty of the manifestation of the crisis, the capacity of known economic models to provide quick solutions in this context has proved to be limited.

The aforementioned international organizations (IMF, WBG, UN) based on macroeconomic analyzes have developed forecasts for the recovery from the crisis, estimates indicating that the economy will begin the recovery process starting in mid2020, 2021 being marked by positive economic growth: 5.8\% according to the IMF, $4.2 \%$ according to WBG and $4.1 \%$ according to the UN. Unfortunately, these estimates are marked by uncertainty, both in terms of the risk of the pandemic prolonging and in the sense of the spread for a longer period of time of the economic and financial imbalances generated by it.

\section{Macroeconomic changes generated by the Covid-19 crisis at European level}

"The corona virus has shaken Europe and the world to its core, testing our healthcare and welfare systems, our societies and economies and our way of living and working together. People have lost their loved ones and their jobs, while plans and futures have been cast into uncertainty. Europe was confronted by a public health challenge that quickly became the most drastic economic crisis in its history." (European Commssion, 2020).

The three important forms of the economic impact of COVID-19 on the global economy are in the opinion of specialists the following (Mishra, 2020):

1. Direct impact on production. Production has already been substantially affected by the shutdown, especially in the area of global industries. Other countries are also beginning to feel a direct impact as their own authorities take similar measures. Slowing down or blocking production in many countries has effects on exporters to other countries. According to the World Bank, even without new outbreaks of disease, these areas are likely to grow slowly in the first half of 2020.

2. Supply chain and market "disturbance". Many manufacturing companies rely on intermediate inputs imported from China and other disease-affected countries. Many companies also rely on Chinese sales to achieve financial goals. The slowdown in economic activity, coupled with transport restrictions in the affected countries, is likely to have an impact on the production and profitability of some global companies, especially in manufacturing and the raw materials used in manufacturing.

3. The impact on financial companies and financial markets. Temporary disruptions of the access to inputs and / or disruption of production could have 
negative effects on firms, especially those with inadequate liquidity. Traders in financial markets may or may not anticipate or understand correctly which companies may be vulnerable. The increase in risk could show that one or more key financial market players have taken unprofitable investment positions in the current conditions, further undermining confidence in financial instruments and these markets.

În termenii rezultatelor economice, recesiunea declanșată de criza Covid-19 la nivelul EU este ușor observabilă pe baza evoluției GDP. Astfel, începând cu anul 2020, evoluția trimestrială a PIB la nivelul UE a înregistrat o scădere cu 3,2\%, comparativ cu trimestrul precedent. (Figura nr. 1) In terms of economic results, the recession triggered by the Covid-19 crisis at EU level is easily observable based on GDP developments. Thus, starting with 2020, the quarterly evolution of GDP at EU level decreased by $3.2 \%$ compared to the previous quarter. (Figure no. 1)

Figure 1

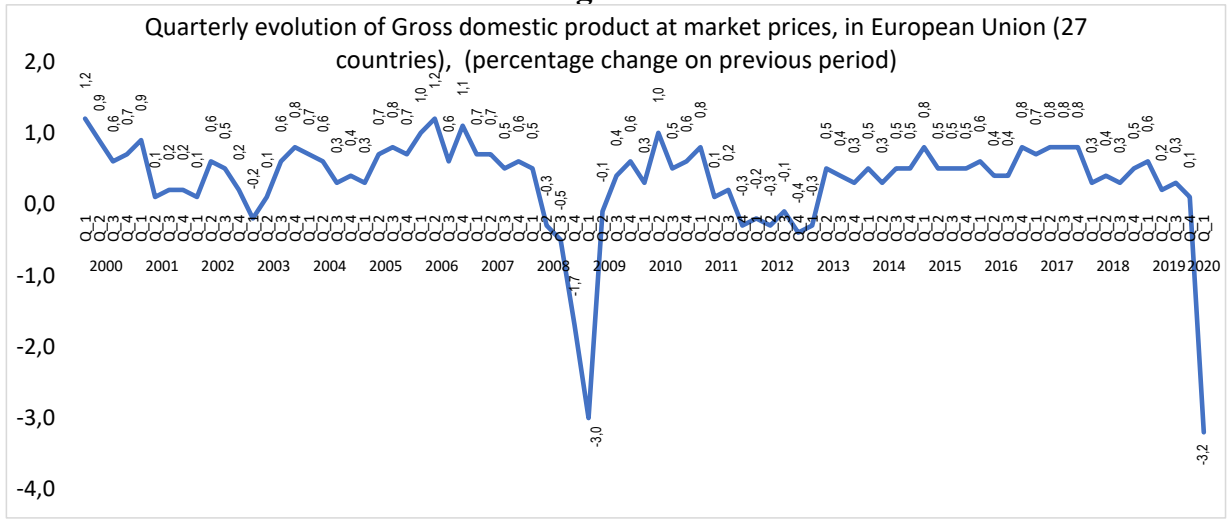

Source: Eurostat, 2020 (accesed at 24.06.2020)

In the context of the recession, questions about how much the European economy will be affected and how long it will last are inherent. Forecasts for the recovery of the EU economy show that after an economic downturn in 2020, in the next year (2021) we will see positive economic growth (Table 2), but these estimates are uncertain mainly due to the impossibility of estimating the period. during which the pandemic will manifest.

Table 2. Estimates of economic growth

\begin{tabular}{|c|c|c|c|c|c|c|}
\hline \multirow{2}{*}{$\begin{array}{c}\text { EU - } \\
27\end{array}$} & \multicolumn{2}{|c|}{ Estimates IFM } & \multicolumn{2}{c|}{ Estimates CE } & \multicolumn{2}{c|}{ Estimări United Nations } \\
\cline { 2 - 7 } & 2020 & 2021 & 2020 & 2021 & 2020 & 2021 \\
\cline { 2 - 7 } & $-7,1$ & 4,8 & $-7,4$ & 6,1 & $-5,5$ & 2,8 \\
\hline
\end{tabular}

Source: International Monetary Fund (2020), European Comission (2020), United Nations (2020)

However, the pessimistic scenarios, which take into account the emergence of a new wave of pandemic, indicate much more pronounced economic declines. For example, in a Communication from the European Commission of 27 May 2020, it was estimated that the percentage of GDP decline at EU level in the context of a second wave, namely the extension of isolation measures, would be $16 \%$ for year 2020 .

Beyond the crisis triggered at the beginning of 2020 by COVID-19, the European economy has entered a trend of slowing down the pace of economic growth since 2019 (see figure no. 1) trend that is part of the one manifested globally. Thus, the United Nations announced in early 2020 that world gross product increased by $2.3 \%$ in 2019 , 
this being the lowest growth rate since the crisis of 2008-2009. So the question arises is it the current crisis triggered by COVID-19, or was it just an accelerator of the entry into recession.

Analyzing the evolution of GDP in recent years and, implicitly, the specific one after the onset of the COVID crisis, it is found that it presents the specific features of the business cycle, being comparable to the evolution of GDP specific to the period before the penultimate crisis that marked the world economy. Comparing the evolution of GDP at the level of the two economic cycles we find that (see figure no. 1):

- the period preceding the penultimate major crisis (2008-2009) was marked, at EU-27 level, by economic growth in the period 2000-2007 (quarterly changes compared to previous positive GDP periods). At this level we distinguish two periods: 2000 - 2003 with a declining GDP growth rate and the period 20042007 , in which economic growth was more accelerated. Since 2007, there has been a slowdown in economic growth and, after this period, starting with the second quarter of 2008, there has been an economic recession, which ended in mid-2009;

- referring to the period following the crisis, from 2008 to 2009, and the one which preceded the Covid-19 crisis (the second economic cycle we are referring to), it can be seen that, similarly, it was marked by economic growth $(2010-2013)$ with lower and, in some places, negative GDP growth rates and the period 2013 - 2018 with comparatively higher GDP growth rates, followed by the slowdown in economic growth starting from the second quarter of 2019 (although it remained a positive one) and recession in the first quarter of 2020. Given the similarities in economic developments over the two periods analyzed, we tend to believe that since 2019 the EU economy was on the verge of recession. Of course, this evolution of GDP can be largely attributed to the impact that Brexit has had on the European economy. Therefore, the hypothesis that the emergence of Covid-19 is an accelerator of the entry into crisis, which will occur (at a slower pace) even in its absence, is very plausible.

An element of differentiation between the two periods of crisis compared is the pace at which GDP fell by more than 3\% in one quarter. Thus, if in the case of the crisis from 2008 to 2009, a decrease of GDP by $3 \%$ (level that represented the maximum point of the crisis) was reached after 4 quarters of negative economic growth; In the current crisis, GDP fell by $3.2 \%$ in the first quarter of the recession, precisely because of the way in which the COVID-19 crisis has left its mark on the economy. Practically, the crisis generated by Covid-19 is not similar in terms of disruptions and evolution with any other crisis that the European Union has faced, many of its effects not being anticipated. (European Commission, 2020)

The impact of the Covid-19 crisis on the various sectors of activity has not been uniform, with sectors where, within a few months of the onset of the crisis, there have been declines to less than half of activity or more, under the impact, in particular, of protection meassures imposed at the level of governments. The first and most affected sectors were those that involved direct contact with the consumer. They practically collapsed immediately after the onset of the crisis, given that restrictions on the spread of the virus were aimed at limiting it and even ceasing activity.

For example, the aviation industry registered a decrease in the number of passengers at European level by $96.8 \%$ between January and April 2020 (Source: ICAO UNITING AVIATION, 2020). Along with transport, tourism has been one of the leading sectors in terms of the impact of the Covid-19 crisis. Thus, according to statistical data, in March 2020 at EU level, nights spent at tourist accommodation establishments decreased by $57.6 \%$ compared to the same month of 2019. (according to Eurostat, 2020) In addition to the sectors where the collapse was immediate, the shock wave spread and continues to spread to other sectors. 
According to estimates by the United Nations Industrial Development OrganizationUNIDO, in the industrialized economies of Europe, manufacturing production decreased by $4.4 \%$ in the first quarter of 2020 , compared to the same period last year, a decrease that continues practically a trend manifested in 2019 , so previously the Covid-19 crisis, triggered as a result of the economic effects generated by Brexit as well as other trade restrictions. However, the decrease rate manifested in 2019 is much lower compared to the one manifested in the first quarter of 2020.

International trade has also been affected by the Covid-19 crisis. In relation to the EU's international trade, it has been on the rise for the last two decades. The manifestation of the Covid-19 crisis led to decreases in imports and exports, the international transactions of EU-27 countries reached in April 2020 values by about 28\% lower in imports and over 30\% in exports than those recorded in April 2019 , being the lowest values in the last 5 years. (Eurostat, 2020)

Similarly at EU level, imports and exports by each of the member states decreased sharply (see Figure 2).

\section{Figure 2}

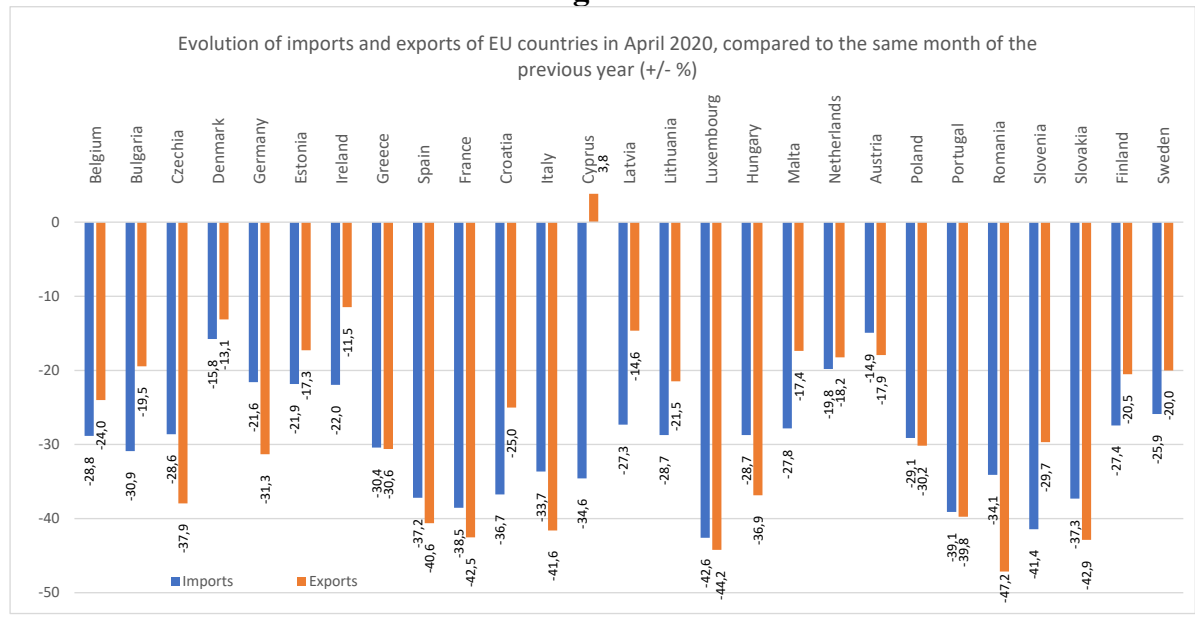

Source: Eurostat, 2020 (accesed at 24.06.2020)

The pandemic affected not only international trade, but trade as a whole, as evidenced by the decline in private consumption. Thus, it is estimated that by the end of 2020, at EU level, private consumption will decrease by $8.5 \%$ (European Commission, 2020). This decline is, on the one hand, alarming in the context of population spending being one of the most important forces of economic growth, but, on the other hand, justifies estimates of the decline in GDP in 2020. For example, in year 2018, for which we have data, private consumption represents $53.4 \%$ compared to the GDP value. (European Commission, 2020)

Of course, consumption has changed not only in terms of value, but also in terms of structure. Thus, on the one hand, the pandemic generated by Covid-19 has led to a decrease in the tendency of the population to spend by reducing, in general, spending on non-essential products and services and, on the other hand, there has been a product orientation toward food (sometimes this category of products exceeds the levels before the onset of the pandemic) and to products for entertainment at home, according to a study conducted in several countries around the world, including Europe. (Jones, 2020) Referring to the evolution of the exchange rate, we find that with the onset of the Covid19 crisis, there was a certain instability of it. Thus, in EU member states outside the euro area, exchange rate fluctuations have been recorded starting with 2020, in the 
sense of the general devaluation of the national currency against the euro (with the exception of Denmark and Bulgaria). On the other hand, the Euro currency devalued in relation to the American and Swiss currencies, a devaluation that manifested itself since 2019, but, at least in relation to the Swiss currency, the fall was much steeper after the outbreak of the pandemic. (see Figure 3).

Figure 3

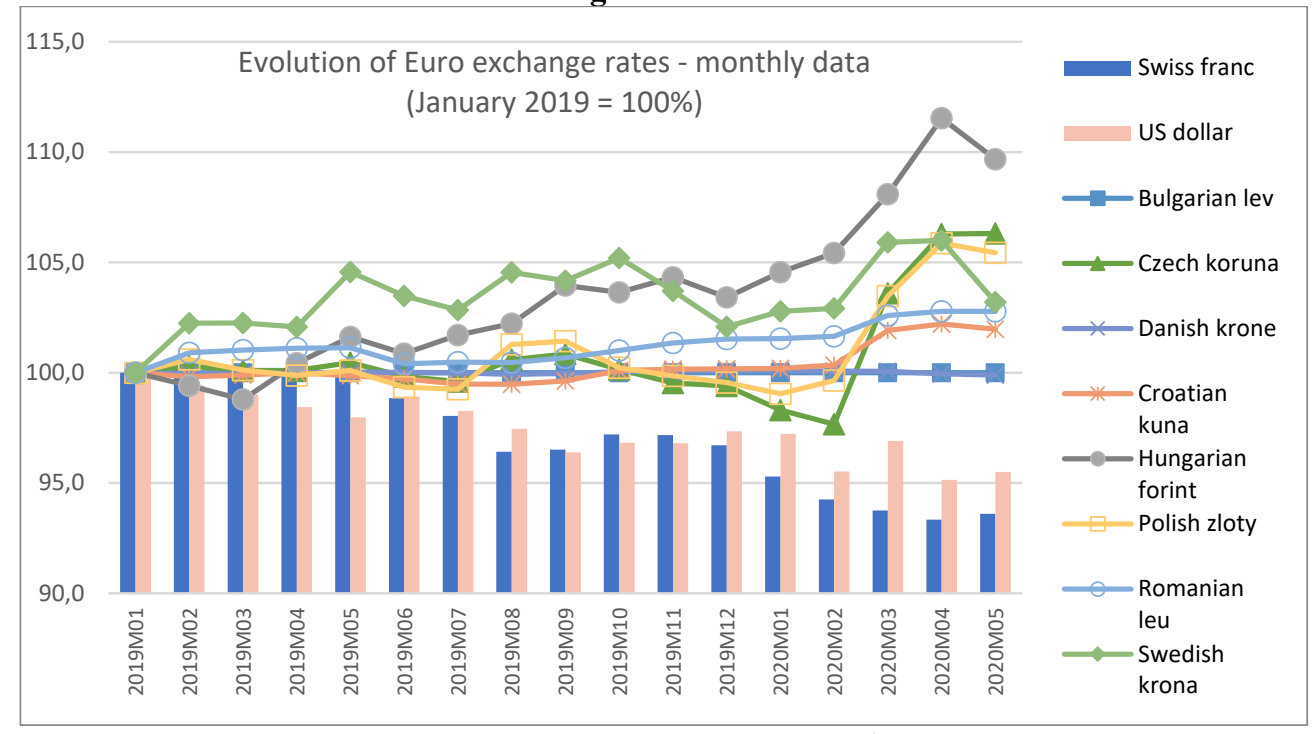

Source: Eurostat, 2020 (accesed at 24.06.2020)

Another problem that has arisen in all the economies affected by the COVID-19 crisis is that of labor market imbalances. According to estimates made by the International Labor Organization in May 2020, at European level (Northern, Southern and Western Europe), the total working hours decreased by $4.3 \%$ in the first quarter of 2020 and by $14,2 \%$ in the second quarter. Regarding unemployment, although in the first four months of 2020 Eurostat data show that at EU level the unemployment rate did not increase, but even decreased compared to at least the same period of 2019, the imbalances generated by Covid-19 will be reflected and in the unemployment rate according to European Commission estimates (9\% in 2020).

\section{The recovery. Scenarios}

There are many scenarios for a recovery from this global crisis. A list of them is summarized by Naharand and Farhan (2020):

1. The economic recovery in the form of $\mathrm{V}$, ie at the end of the acute period of the pandemic (closure of activities) we will witness a rapid return to economic normalcy. This evolution was also anticipated in Romania by the government in the first weeks of the pandemic. Although some of the economic data after the lifting of the state of emergency seemed to be encouraging, such as the volume of turnover for retail trade (https://www.money.ro/citu-anunta-inca-odovada-pentru-revenirea -in-your-economy-turnover-volume-for-retail-tradeincreased-compared-to-the-same-period-of-the-previous-year-we-prepare-ec ), subsequent data have suggested rather another type of evolution, less accelerated. The source of such a development is, in the opinion of the supporters, the economic support programs promised at almost all countries affected by the crisis. 
2. U-shaped economic recovery. This development means that it will take longer to return to economic normalcy. This form of recovery seems to be more in line with the situation where the reopening of economies will be progressive and the situation will be different from before the pandemic. The famous Nouriel Roubini claimed that the return after the current crisis will be in the "U", or even "a little closer to an L" - a recession similar to the Great Depression of the 1930s, with a drastic decline and a stagnation spread over several years, not just for a few quarters. Moreover, the same Roubini stated that during the global financial crisis (from 2008-2009) production took three years to record a sharp decline. This time it didn't take three years, not even three months. In three weeks we had a sudden collapse on each component (https://www.bursa.ro/nouriel-roubini-revenirea-economica-va-fi-in-u-sauchiar-mai-aproape-de-un-1-87,186,934).

3. W-shaped or double-drained economic recovery means that, after a slight recovery, we will witness a fall again and then a final economic recovery. This development would be possible in the event of the rapid disappearance of the initial effect of the monetary and fiscal measures put in place to combat the coronavirus.

4. L-shaped economic recovery, this being the most unfavorable evolution associated with the pandemic crisis. Specifically, such an evolution would mean that the time required to return would be a long one. It is the darkest economic scenario and would involve strong changes not only at the economic but also social level. Unfortunately, some specialists appreciate that such a return could be valid for Romania as well. Thus, the Gross Domestic Product decreased in the second quarter, compared to the first three months of the year, by $12.3 \%$, and compared to the same quarter of 2019 the decrease is $10.5 \%$, according to the National Institute of Statistics. Although this decrease is lower than the average in the European Union, 14.4\% according to Eurostat, we must not forget the dependence of the Romanian economy on the most important European economies.

Such scenarios are the result of individual and collective action by states affected by the pandemic. Obviously, the results are different depending on the characteristics, potential, commitment of each of the states / areas affected by the economic crisis.

In general, the areas of action in this context are the following (Mishra, 2020):

\section{Fiscal area}

Rich countries have introduced massive health care programs and increased public spending to counter the economic effects of the COVID-19 pandemic. For poorer countries, options for fiscal and monetary action are more limited, with an important role that international financial organizations can play here. Most developed countries have provided important economic responses to the COVID-19 pandemic, accelerating spending and using monetary policy to cushion the shock generated by the closure of some economic sectors.

\section{Macroeconomic and development policy area}

In response to the escalating medical emergency and the rapidly deteriorating economic outlook, national authorities and multinational entities around the world are considering unprecedented economic policies. Central banks in developed and developing countries have moved aggressively to help avert the crisis, lowering interest rates, injecting liquidity and providing emergency financing for businesses and households. This is also the case in Romania, where the National Bank has reduced the monetary policy interest rate (https://www.bnr.ro/Politica-monetara-4311-Mobile.aspx), and the government has developed and implemented projects to support the business environment, such as SME invest. Such direct support measures can play an important role in limiting short-term socio-economic effects, while maintaining the capacity for 
prompt recovery. Such measures may also include tax deferrals, governmentsubsidized short-term employment incentive schemes, moratoriums on mortgage payments and direct cash payments. Very importantly, social protection programs need to reach those most in need during the crisis, with a focus on the elderly and those in vulnerable situations.

\section{The area of markets for essential goods and services}

Governments need to address the basic issues of supply and demand for essential goods, in order to prevent shortages and increase prices in the short term. It is essential to ensure the production and distribution of food and medicine, which in turn requires the maintenance of transport and basic public services (water, energy and communications).

\section{Foreign exchange market area}

In order to avoid a depreciation of the domestic currency as a result of the cessation of economic activity, such as exports, governments will most likely have to establish controls over foreign exchange transactions. The government must be able to manage foreign exchange reserves by calculating the cash flow needed to finance imports of food, medicine, energy and other basic materials for at least six months, taking into account the dynamics of external debt.

\section{Area of international organizations}

International organizations are important players in critical episodes of international politics, with power in mediation, dispute resolution, peacekeeping, sanctions and more. They also help manage various key areas of international interest, from global health policy to monetary policies around the world (Abbott and Snidal, 1998). The COVID-19 crisis has shown how important international institutions in various fields are for collective health and safety. The efforts of the World Health Organization, the World Bank Group, the OECD can be key to resolving global crises. They can support concentrated and effective measures in economies that need to address the health, economy, employment and social impact of the pandemic.

\section{Investment area}

Foreign direct investment (FDI) has become an important factor in the development of capital, in the creation of new jobs, in the transfer of technology and skills from one market to another. Some developing countries have seen major benefits from these investments in terms of economic development and rising living standards. FDI can also play a significant role in financing the achievement of the Sustainable Development Goals on basic infrastructure, food security, climate change mitigation and adaptation, health and education. To do this, governments need to mobilize private investment more effectively, channel it into sustainable development sectors and maximize their positive economic, social and environmental impact.

Such areas of action can lead to the identification of the most effective strategies and concrete actions to solve the crisis generated by the pandemic. Obviously, a specific calibration is needed depending on the characteristics of each economy.

\section{Conclusions}

In the presented context, knowing the present, the question arises: what will be the longterm impact that the Covid-19 pandemic will have on the national and global economic evolution. Moreover, we can continue to ask ourselves whether the economic crisis of 2008-2009 or that of 1929-1933 and how to solve them can be a model for estimating the evolution of the economy in the next period. Or, given the triggering factor or, as the case may be, the factor that accelerated the entry into the crisis, can the alleged crises be compared? We can also ask ourselves whether it is realistic that the objective (s) of the recovery measures are associated with a return to what was before the crisis (as happened in the 2008-2009 crisis) or the preparation of the economy and policies. 
sectoral, on new coordinates, completely different to respond to new developments in the world, is rather the solution.

Of course, the answers will come as time passes and this new phenomenon for the contemporary world will reveal all its surprises.

\section{References}

Abbott, Kenneth. (1998). Why States Act Through Formal International Organizations. Journal of Conflict Resolution. 42. 3. 10.1177/0022002798042001001.

Cojocaru B. (2020), Criza COVID-19: unde se vor duce economiile dezvoltate? Mult în jos. Cât de mult? Nimeni nu ştie. Se ştie însă că unele vor suferi mai mult decât altele, iar cele mai vulnerabile se anunţă a fi ţările supraîndatorate din sudul Europei, Ziarul financiar, disponibil la: https://www.zf.ro/banci-siasigurari/criza-covid-19-unde-vor-duce-economiile-dezvoltate-mult-jos-catmult-19084131;

Jones, K. (2020), How COVID-19 Consumer Spending is Impacting Industries, Visual Capitalist, available at: https://www.visualcapitalist.com/consumer-spendingimpacting-industries/;

Totir, F.C., Dragotă, I.M. (2011), Criza economică şi financiară actuală - aspecte noi sau revenirea la vechile probleme? Paradigme, cauze, efecte şi soluţii adoptate, Economie teoretică şi aplicată, Volumul XVIII (2011), No. 1(554), pp. 131153, available at: http://store.ectap.ro/articole/547_ro.pdf;

Autoritatea de Supraveghere Financiară (2020), Raport privind stabilitatea piețelor financiare nebancare, $n r .1$ / 2020, disponibil pe: https://asfromania.ro/files/analize/Raport_stabilitate_piete_financiare_nebanca re_14052020.pdf;

Banca Centrală Europeană, Proiecțiile macroeconomice pentru zona euro ale experților $B C E$, martie 2020, available at: https://www.ecb.europa.eu/pub/projections/html/ecb.projections202003_ecbsta ff $\sim$ dfa19e18c4.ro.html\#toc1;

European Commission (2020), Communication from The Commission to the European Parliament, The European Council, The Council, The European Economic and Social Committe and The Committee Of The Regions. Europe's moment: Repair and Prepare for the Next Generation, available at: https://eurlex.europa.eu/legalcontent/EN/TXT/?qid=1590732521013\&uri=COM:2020:456:FIN;

European Commission (2020), European Economic Forecast, Spring 2020, available at: https://ec.europa.eu/info/sites/info/files/economy-finance/ip125_en.pdf;

Eurostat, 2020, How Covid-19 is changing the world: a statistical perspective, available at: https://unstats.un.org/unsd/ccsa/documents/covid19-report-ccsa.pdf;

ICAO UNITING AVIATION, 2020, Effects of Novel Coronavirus (COVID-19) on Civil Aviation: Economic Impact Analysis, available at: https://www.icao.int/sustainability/Documents/COVID-

19/ICAO\%20COVID\%202020\%2006\%2015\%20Economic\%20Impact.pdf;

International Labour Organization, 2020, ILO Monitor: COVID-19 and the world of work. Fourth edition Updated estimates and analysis, available at: https://www.ilo.org/wcmsp5/groups/public/@dgreports/@dcomm/documents/ briefingnote/wcms_745963.pdf;

International Monetary Fund (2020), World Economic Outlook, April 2020: The Great Lockdown, available

at: https://www.imf.org/en/Publications/WEO/Issues/2020/04/14/weo-april-2020 ;

Mishra, Mukesh Kumar (2020) : The World after COVID-19 and its impact on Global Economy, ZBW - Leibniz Information Centre for Economics, Kiel, Hamburg; 
Naharand, Lutfun - Farhan, Naimul Islam. "The Future of Global Economy Post COVID-19", Analysis INSAMER, 17.06.2020.

United Nations. Industrial Development Organization (2020), World Manufacturing Production. Statistics for Quarter I, 2020, available at: https://www.unido.org/sites/default/files/files/202006/World_manufacturing_production_2020_Q1.pdf;

United Nations (2020), World Economic Situation Prospects 2020, available at: https://unctad.org/en/PublicationsLibrary/wesp2020 en.pdf;

United Nations (2020), World Economic Situation and Prospects as of mid-2020, available at: https://www.un.org/development/desa/dpad/wpcontent/uploads/sites/45/publication/WESP2020_MYU_Report.pdf;

The World Bank (2020), COVID-19 to Plunge Global Economy into Worst Recession since World War II, available at: https://www.worldbank.org/en/news/pressrelease/2020/06/08/covid-19-to-plunge-global-economy-into-worst-recessionsince-world-war-ii;

World Bank Group (2020), Global Economic Prospects, June 2020, available at: https://www.worldbank.org/en/publication/global-economic-prospects;

Eurostat (2020), Database, available at: https://ec.europa.eu/eurostat/data/database.

https://www.bnr.ro/Politica-monetara-4311-Mobile.aspx

https://www.bursa.ro/nouriel-roubini-revenirea-economica-va-fi-in-u-sau-chiar-maiaproape-de-un-1-87186934

https://www.money.ro/citu-anunta-inca-o-dovada-pentru-revenirea-in-v-a-economieivolumul-cifrei-de-afaceri-pentru-comertul-cu-amanuntul-a-crescut-fata-deaceeasi-perioada-a-anului-precedent-pregatim-ec/ 